\title{
Effects of Ammonia and Ammonium on Tolerance and Byssogenesis in Perna viridis
}

\author{
N. A. Reddy and N. R. Menon \\ University of Agricultural Sciences, College of Fisheries, Mangalore - 575002, India
}

\begin{abstract}
Individuals of the commercially important green mussel Perna viridis (Kuriakose and Nair, 1976) were exposed to different concentrations of ammonia $\left(\mathrm{NH}_{3}\right)$ and ammonium $\left(\mathrm{NH}_{4}^{+}{ }_{4}\right)$, to determine their reactions with reference to tolerance and byssogenesis. Eight concentrations of ammonia, ranging from 2.75 to $33.00 \mathrm{mg} \mathrm{l}^{-1}$, and 7 concentrations of ammonium, ranging from 5.00 to $75.00 \mathrm{mg} \mathrm{l}^{-1}$, were tested. Young individuals in the size range 20 to $24 \mathrm{~mm}$ shell length, collected from an unpolluted rocky shore, were used as test organisms. The 96 -h lethal concentration causing $50 \%$ mortality (LC 50 ) was $7.60 \mathrm{mg} \mathrm{l}^{-1}$ for $\mathrm{NH}_{3}$ and $13.00 \mathrm{mg} \mathrm{^{-1 }}$ for $\mathrm{NH}^{+}{ }_{4}$. For ammonia, the difference between LC 50 values at 48 and at $96 \mathrm{~h}$ is drastic. In sublethal concentrations $P$. viridis retarded or suspended pedal-gland activity. A sharp reduction in the number of threads produced occurs at 5.50 and $8.25 \mathrm{mg} \mathrm{l}^{-1}$ of ammonia. At higher concentrations the byssus threads secreted displayed reduced rates of tanning and hardening. The difference in the number of byssus threads produced at various ammonia concentration was highly significant. Compared to controls the discs developed at the tips of the byssus threads did not possess normal adhesive properties.
\end{abstract}

\section{INTRODUCTION}

This paper is part of an investigation of the ecology of waters off Mangalore (Arabian Sea), which receive effluents comprising mainly urea and ammonia from a fertilizer complex. Perna viridis (Syn. Mytilus viridis) forms extensive beds on the rocky shores along the coast of Mangalore. This species is regularly exploited by local fishermen. The analysis of its tolerance to various concentrations of ammonia and their effect on byssogenesis can help to elucidate potential influences of ammonia on essential life processes of this commercially important bivalve.

Information on the effect of $\mathrm{NH}_{3}$ and $\mathrm{NH}^{+}{ }_{4}$ on the life processes of marine organisms is scarce (for a review consult 'Marine Ecology' Volume III: Kinne, 1976, pp. 80-93). Working on the effects of ammonium nitrate on fertilization and early development of Chromytilus meridionalis (Brown, 1974) found that concentrations as low as $0.5 \mathrm{ppm}$ retard early development. Currie et al. (1974) obtained similar results. Brown and Currie (1973) determined the tolerance of Bullia digitalis to solutions of $\mathrm{NH}_{4} \mathrm{NO}_{3}$ in natural sea water.

\section{MATERIAL AND METHODS}

The green mussel Perna viridis (Kuriakose and Nair, 1976) was collected from an unpolluted region at

(c) by Inter-Research
Someswara rocky shore $\left(12^{\circ} 47^{\prime} \mathrm{N} ; 74^{\circ} 51^{\prime} \mathrm{E}\right)$. All individuals were obtained during low tide from the subtidal belt. They were transported to the laboratory and kept unfed in large polythene trays, in aerated sea water for $24 \mathrm{~h}$ before commencement of the experiments. Young mussels in the size range 20 to $24 \mathrm{~mm}$ were used for the experiments. In a single set of experiments only members of the same population were examined.

Liquor ammonia, containing $25 \%$ free ammonia was the source of molecular ammonia $\left(\mathrm{NH}_{3}\right)$ and ammonium sulphate was the source of ammonium $\left(\mathrm{NH}^{+}{ }_{4}\right)$. Mortality tests were conducted over $96 \mathrm{~h}$. Inability to close the valves upon mechanical stimulus and valve gaping of $5 \mathrm{~mm}$, were the criteria used to define death. To check the possibility of revival, those mussels considered dead by the above criteria were exposed to normal control conditions for $24 \mathrm{~h}$. Dead individuals were removed from the experimental media at $12 \mathrm{~h}$ intervals. The experimental vessels were cylindrical glass troughs of $5 \mathrm{l}$ capacity containing $4 \mathrm{l}$ filtered sea water. Ten mussels were exposed to each concentration (Table 2 and 3). Byssus-thread formation was calculated as the number of threads secreted by one mussel. Readings were taken at $12 \mathrm{~h}$ intervals (at 0600 and $1800 \mathrm{~h}$ ). Since the majority of the threads formed developed adhesive discs, these discs were counted and then the whole byssal mass (stem and threads) was cut-off flush with the valves, and the 
mussels were left in the test solution. In assessing the percentage of mussels which had attached, only the presence of byssus threads with adhesive discs was taken into consideration. It was found that cutting off the threads does not affect further byssogenesis.

Table 1. Concentrations of ammonia $\left(\mathrm{NH}_{3}\right)$ in various test solutions and their respective $\mathrm{pH}$ values. $\mathrm{pH}$ of control sea water $=\mathrm{pH} 8.05$

\begin{tabular}{|cc|}
\hline $\begin{array}{c}\mathrm{NH}_{3} \\
\left(\mathrm{mg} \mathrm{I}^{-1}\right)\end{array}$ & $\mathrm{pH}$ \\
\hline 1.375 & 8.225 \\
2.750 & 8.325 \\
5.500 & 8.475 \\
8.250 & 8.600 \\
11.000 & 8.700 \\
16.500 & 8.850 \\
22.000 & 9.000 \\
33.000 & 9.200 \\
\hline
\end{tabular}

\section{RESULTS}

The amount of the molecular form of ammonia increases conspicuously in the $\mathrm{pH}$ range of 8.0 to 9.5. The water temperature also plays a marked role in dissociation of $\mathrm{NH}_{3}$ from its source. Waters of high temperature and high $\mathrm{pH}$ will therefore contain a high amount of the molecular form of ammonia, irrespective of the total ammonia concentration (Fig. 1). During the present study, the $\mathrm{pH}$ of the sea water varied between 8.0 and 8.3 , the temperature between $28.0^{\circ}$ and $30.0^{\circ} \mathrm{C}$. The addition of liquor ammonia greatly affected the $\mathrm{pH}$ of the test solution. Thus, an increase in $\mathrm{NH}_{3}$ concentration from 1.375 to $33 \mathrm{mg} \mathrm{l} \mathrm{l}^{-1}$ altered the $\mathrm{pH}$ from 8.225 to 9.200 . The increase in $\mathrm{pH}$ was directly proportional to the increase in $\mathrm{NH}_{3}$ concentration (Table 1).

\section{MORTALITY}

\section{Lethal Effects of Ammonia}

Death prevailed in 5.5 and $8.25 \mathrm{mg} \mathrm{l}^{-1} \mathrm{NH}_{3}$ after $48 \mathrm{~h}$ exposure. $100 \%$ mortality occurred before $96 \mathrm{~h}$ at 16.5 and $22.0 \mathrm{mg} \mathrm{1}^{-1}$. No mussels kept at $33.0 \mathrm{mg} \mathrm{l}^{-1}$ survived beyond $36 \mathrm{~h}$ (Table 2; Fig. 2).

ET 50 values worked out from the results obtained on mortality are presented in Figure 2. It is clear from this

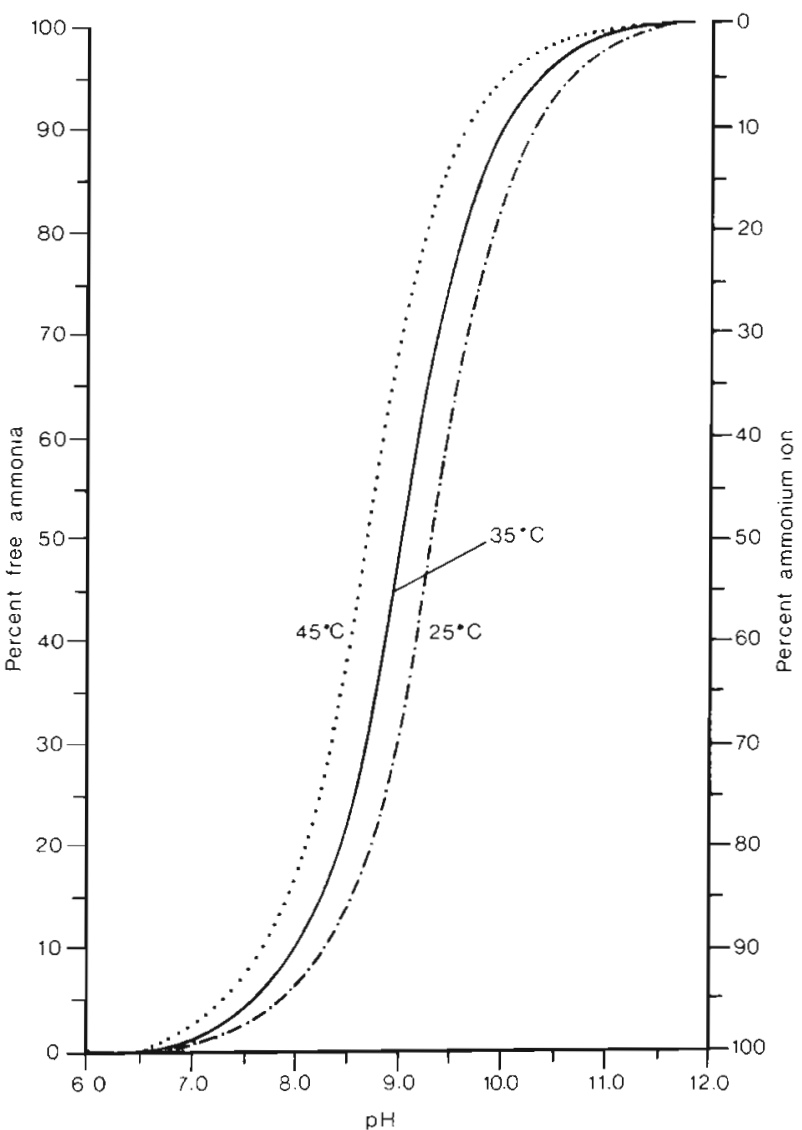

Fig. 1. Per cent free ammonia as a function of $\mathrm{pH}$ and temperature. (After Wuhurmann, 1947)

Table 2. Perna viridis. Cumulative percentage mortality of individuals exposed to different $\mathrm{NH}_{3}$ concentrations

\begin{tabular}{|c|c|c|c|c|c|c|c|c|}
\hline \multirow{2}{*}{$\begin{array}{c}\mathrm{NH}_{3} \text { Concentration } \\
\left(\mathrm{mg} \mathrm{l}^{-1}\right)\end{array}$} & \multicolumn{8}{|c|}{ Time (h) } \\
\hline & 12 & 24 & 36 & 48 & 60 & 72 & 84 & 96 \\
\hline Control: & 0 & 0 & 0 & 0 & 0 & 0 & 0 & 0 \\
\hline 2.75 & 0 & 0 & 0 & 0 & 0 & 0 & 0 & 0 \\
\hline 5.50 & 0 & 0 & 0 & 20 & 20 & 20 & 20 & 20 \\
\hline 8.25 & 0 & 0 & 0 & 20 & 20 & 20 & 40 & 50 \\
\hline 11.00 & 0 & 0 & 0 & 20 & 40 & 40 & 60 & 100 \\
\hline 13.75 & 0 & 0 & 0 & 40 & 40 & 60 & 80 & 100 \\
\hline 16.50 & 0 & 0 & 20 & 40 & 40 & 80 & 100 & \\
\hline 22.00 & 0 & 40 & 60 & 100 & & & & \\
\hline 33.00 & 0 & 60 & 100 & & & & & \\
\hline
\end{tabular}


Table 3. Perna viridis. Cumulative percentage mortality of individuals exposed to different $\mathrm{NH}_{4}{ }^{+}$concentrations

\begin{tabular}{|c|c|c|c|c|c|c|c|c|}
\hline \multirow{2}{*}{$\begin{array}{c}\mathrm{NH}_{4}+\text { Concentration } \\
\left(\mathrm{mg} \mathrm{l}^{-1}\right)\end{array}$} & \multicolumn{8}{|c|}{ Time (h) } \\
\hline & 12 & 24 & 36 & 48 & 60 & 72 & 84 & 96 \\
\hline Control: & 0 & 0 & 0 & 0 & 0 & 0 & 0 & 0 \\
\hline 5 & 0 & 0 & 0 & 0 & 0 & 0 & 0 & 0 \\
\hline 10 & 0 & 10 & 20 & 20 & 20 & 20 & 20 & 20 \\
\hline 15 & 0 & 20 & 60 & 60 & 70 & 70 & 70 & 80 \\
\hline 20 & 0 & 30 & 50 & 80 & 80 & 90 & 90 & 90 \\
\hline 50 & 0 & 20 & 90 & 100 & & & & \\
\hline 75 & 0 & 30 & 100 & & & & & \\
\hline
\end{tabular}

Fig. 2. Perna viridis. Mortality of individuals exposed to different $\mathrm{NH}_{3}$ concentrations

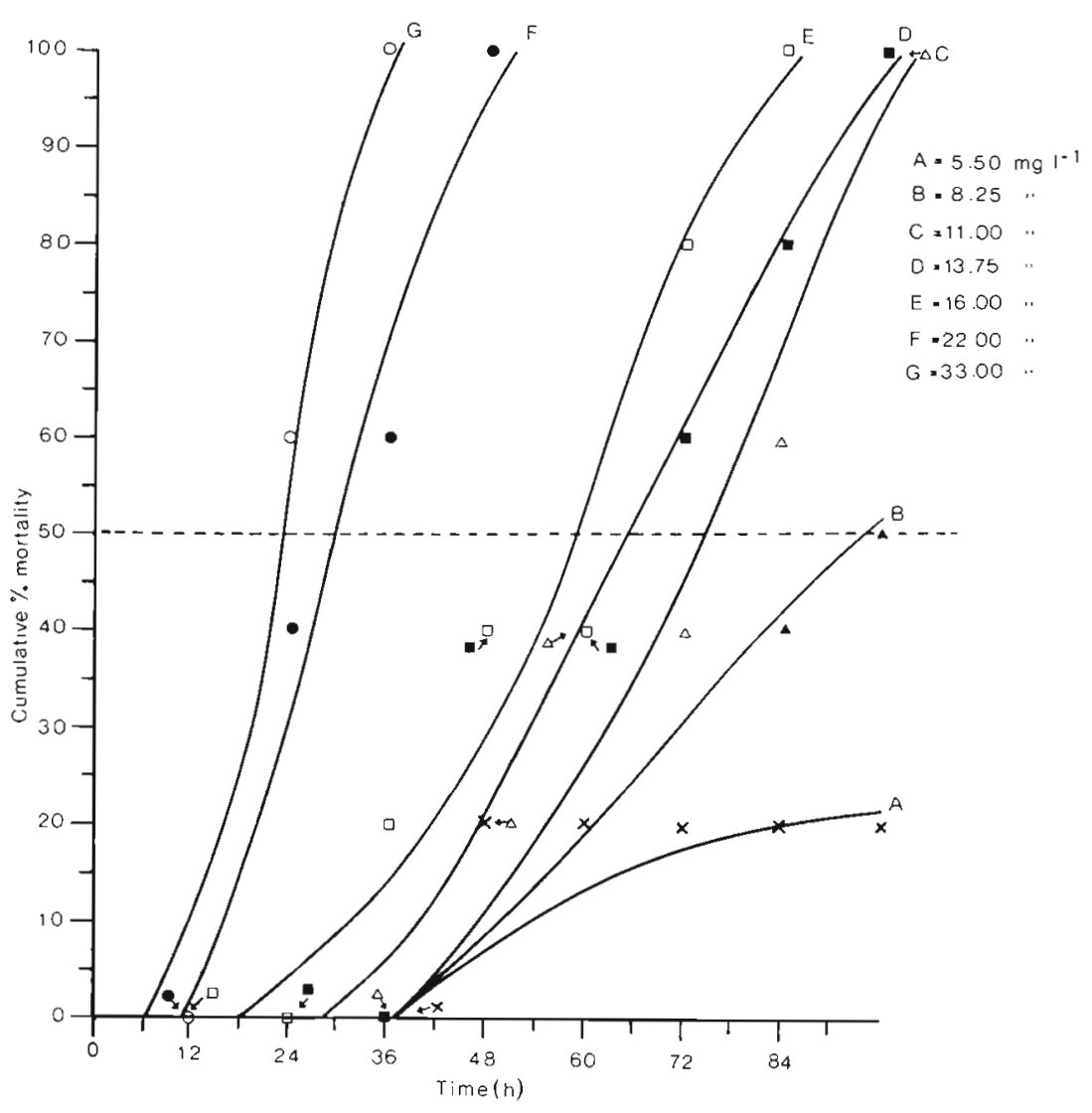

Table 4. Perna viridis. Average number of byssus threads secreted by individuals exposed to various $\mathrm{NH}_{3}$ concentrations. $\mathrm{D}=$ dark; $\mathrm{L}=$ light

\begin{tabular}{|c|c|c|c|c|c|c|c|c|}
\hline \multirow{3}{*}{$\begin{array}{c}\mathrm{NH}_{3} \text { Concentration } \\
\left(\mathrm{mg} \mathrm{l}^{-1}\right)\end{array}$} & \multicolumn{8}{|c|}{ Time (h) } \\
\hline & $\mathrm{D}$ & $\mathrm{L}$ & $\mathrm{D}$ & $\mathrm{L}$ & $\mathrm{D}$ & L & $\mathrm{D}$ & $\mathrm{L}$ \\
\hline & 12 & 24 & 36 & 48 & 60 & 72 & 84 & 96 \\
\hline Control: & 46.2 & 40.4 & 54.2 & 47.0 & 54.0 & 34.6 & 76.0 & 47.6 \\
\hline 2.75 & 30.4 & 32.2 & 37.2 & 25.0 & 44.5 & 23.4 & 68.6 & 41.0 \\
\hline 5.50 & 9.6 & 7.6 & 11.4 & 12.0 & 15.4 & 9.0 & 26.4 & 16.0 \\
\hline 8.25 & 1.2 & 0 & 1.0 & 0 & 0.4 & 0 & 1.4 & 0 \\
\hline 11.00 & 0 & 0 & 0.6 & 0 & 1.0 & 0.4 & 0 & 0 \\
\hline 13.75 & 0 & 0 & 0.6 & 0 & 0 & 0 & 0 & 0 \\
\hline 16.50 & 0 & 0 & 0 & 0 & 0 & 0 & 0 & 0 \\
\hline 22.00 & 0 & 0 & 0 & 0 & 0 & 0 & 0 & 0 \\
\hline
\end{tabular}


figure that a conspicuous difference in time exists for the incidence of $50 \%$ mortality between concentrations of 16.5 and $20.0 \mathrm{mg} \mathrm{l}^{-1}$. The lethal concentration causing $50 \%$ mortality (LC 50 ) in a given length of time values were derived for different concentrations. Figure 2 shows that the 48 -h LC 50 is $14.0 \mathrm{mg} \mathrm{l}^{-1}$ the
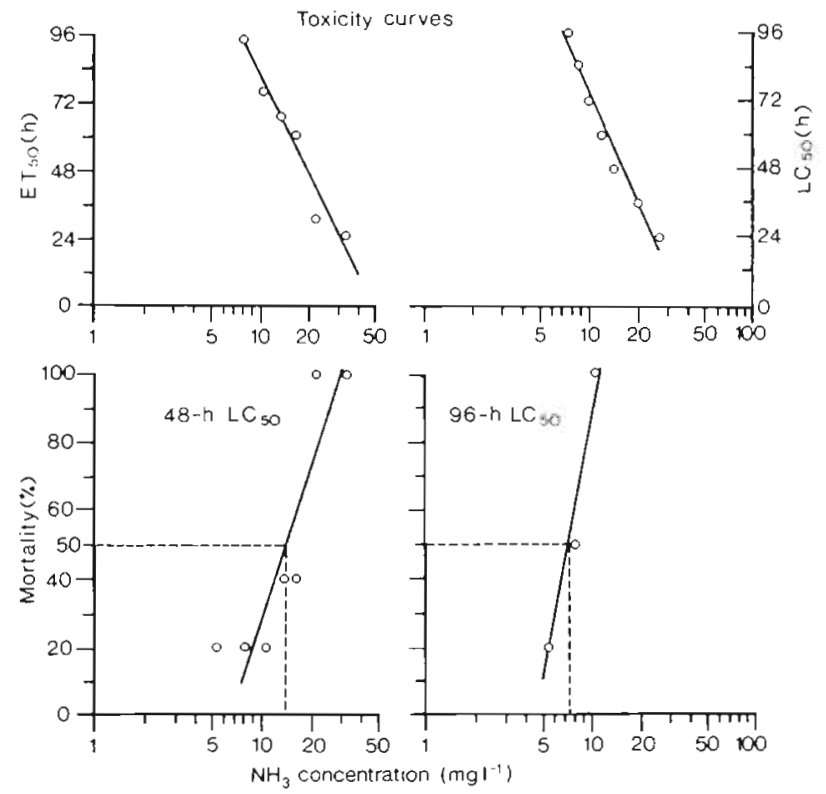

Fig. 3 Perna viridis. Median lethal concentrations (LC 50) for different $\mathrm{NH}_{3}$-exposure times and toxicity curves

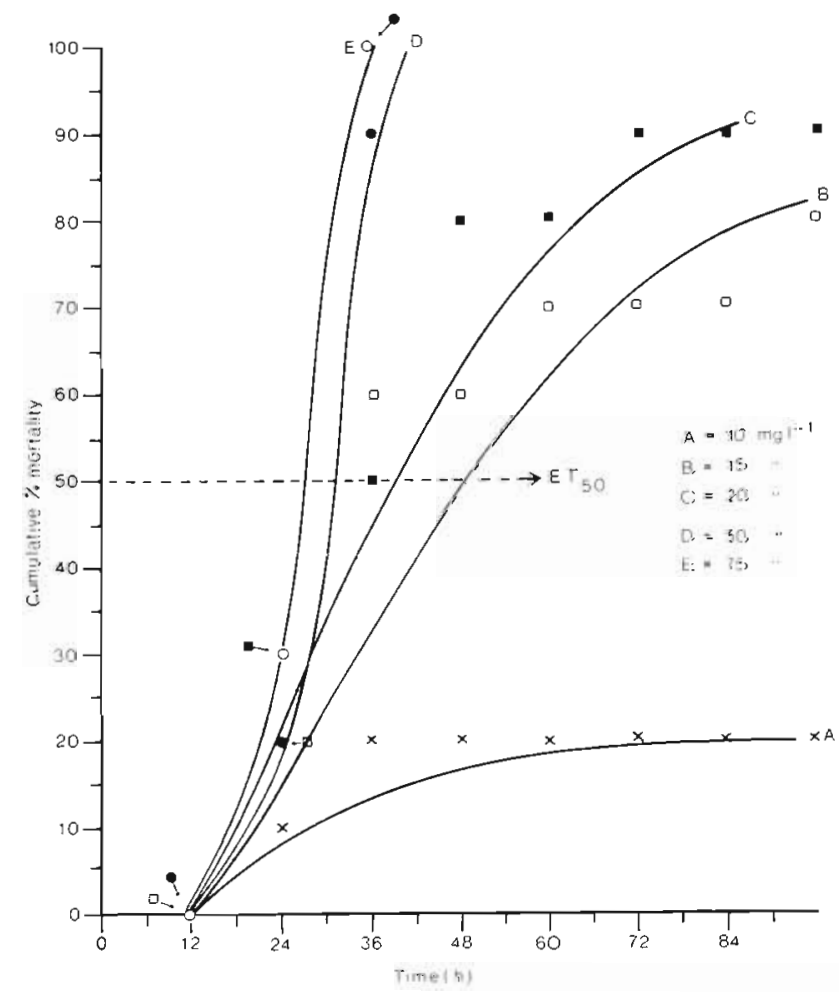

Fig. 4. Perna viridis. Mortality of individuals exposed to different $\mathrm{NH}_{4}^{+}$concentrations 96-h LC 50, $7.6 \mathrm{mg} \mathrm{l}^{-1}$ (Fig. 3). The $5 \%$ confidence limits varied between 13.0 and $15.5 \mathrm{mg} \mathrm{l}^{-1}$ for $48 \mathrm{~h}$ and between 7.2 and $7.8 \mathrm{mg} \mathrm{l}^{-1}$ for $96 \mathrm{~h}$.

\section{Lethal Effects of Ammonium}

Ammonium sulphate at various concentrations was used so as to derive $\mathrm{NH}_{4}^{+}$values ranging from 5.0 to $75.0 \mathrm{mg} \mathrm{l}^{-1}$. A slight reduction in $\mathrm{pH}$ occurred upon addition of $\left(\mathrm{NH}_{4}\right)_{2} \mathrm{SO}_{4} ; \mathrm{pH}$ of the media ranged from $8.125\left(5.0 \mathrm{mg} \mathrm{l}^{-1}\right)$ to $7.85\left(75.0 \mathrm{mg} \mathrm{l}^{-1}\right)$.

Mortality data are presented in Table 3.80 and $90 \%$ of the test individuals were killed after $96 \mathrm{~h}$ exposure in 15.0 and $20.0 \mathrm{mg} \mathrm{l}^{-1} \mathrm{NH}_{4}^{+}$, respectively. $100 \%$ mortality occurred in $48 \mathrm{~h}$ at $50.0 \mathrm{mg} \mathrm{l}^{-1}$ and in $36 \mathrm{~h}$, at $75.0 \mathrm{mg} \mathrm{l}^{-1}$. The ET 50 values, computed from mortality rates, show that $50 \%$ of the test organisms died within $49.8 \mathrm{~h}$ at $15.0 \mathrm{mg} \mathrm{l}^{-1}$, whereas $50 \%$ died after $30 \mathrm{~h}$ at $75.0 \mathrm{mg} \mathrm{l}^{-1}$. Curiously, the difference between the ET 50 values for 50.0 and for $75.0 \mathrm{mg} \mathrm{l}^{-1}$ is only $1.8 \mathrm{~h}$ (Fig. 4). The LC 50 values were derived from the mortality rates. The 48 -h LC 50 was $15.5 \mathrm{mg} \mathrm{l}^{-1}$; the 96 -h LC 50 , $13.0 \mathrm{mg} \mathrm{l}^{-3}$. The $5 \%$ confidence limits for the duration of 48 and $96 \mathrm{~h}$ range from 13.75 to $16.00 \mathrm{mg} \mathrm{l}^{-1}$ and 12.50 and $14.00 \mathrm{mg} \mathrm{l}^{-1}$, respectively (Fig. 5).

\section{BYSSOGENESIS}

The process of byssus-thread secretion by some Bivalvia is referred to as byssogenesis. The rate of production, the nature of secretion, the structure of
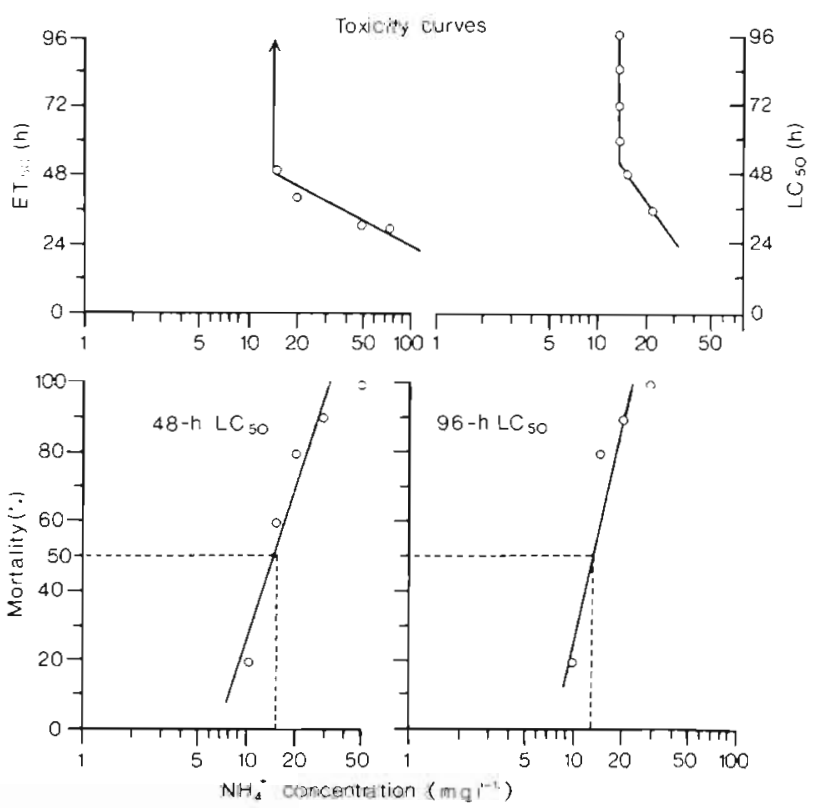

Fig. 5 Perna viridis. Median lethal concentrations (LC 50) for different $\mathrm{NH}_{4}^{+}$-exposure times and toxicity curves 


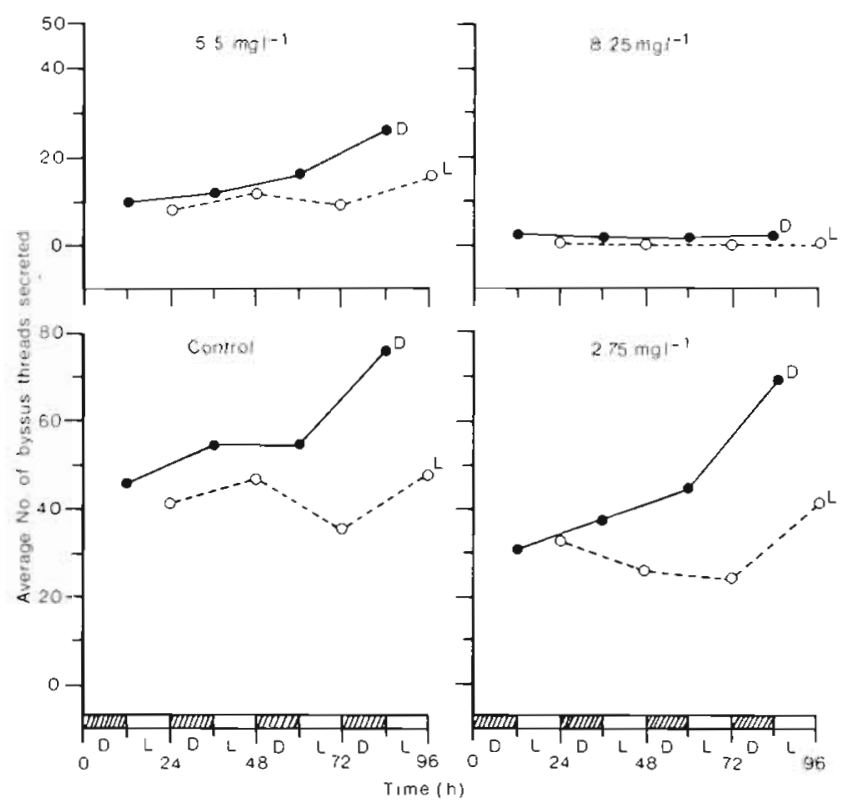

Fig. 6. Perna viridis. Rate of byssus-thread secretion by individuals exposed to different $\mathrm{NH}_{3}$ concentrations

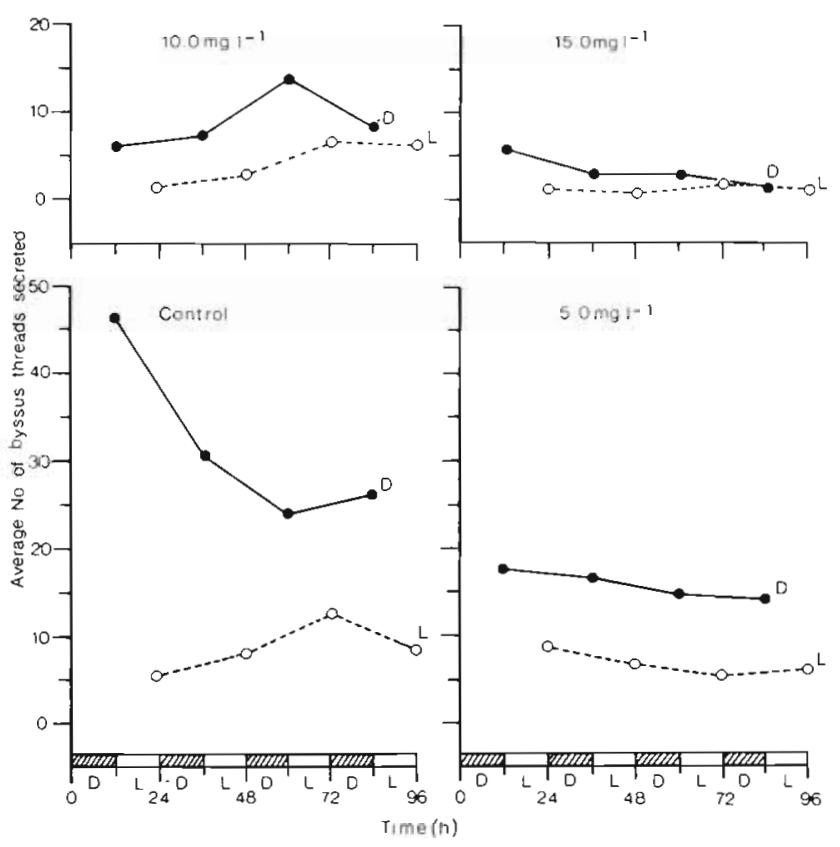

Fig. 7. Perna viridis. Rate of byssus-thread secretion by individuals exposed to different $\mathrm{NH}_{4}^{+}$concentrations

Table 5. Perna viridis. Percentage of mussels secreting byssus threads at 12 -h intervals in various $\mathrm{NH}_{3}$ concentrations. $\mathrm{D}=$ dark; $\mathrm{L}=$ light

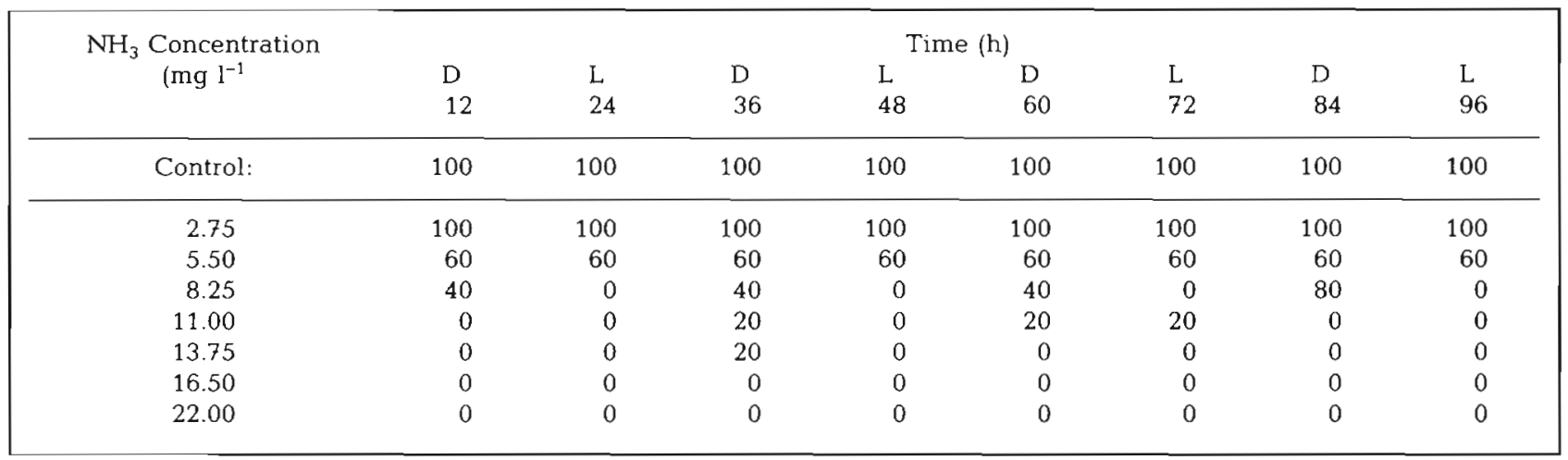

Table 6. Perna viridis. Average number of byssus threads secreted at 12 -h intervals by individuals exposed to various $\mathrm{NH}_{4}{ }^{+}$ concentrations. $\mathrm{D}=$ dark; $\mathrm{L}=$ light

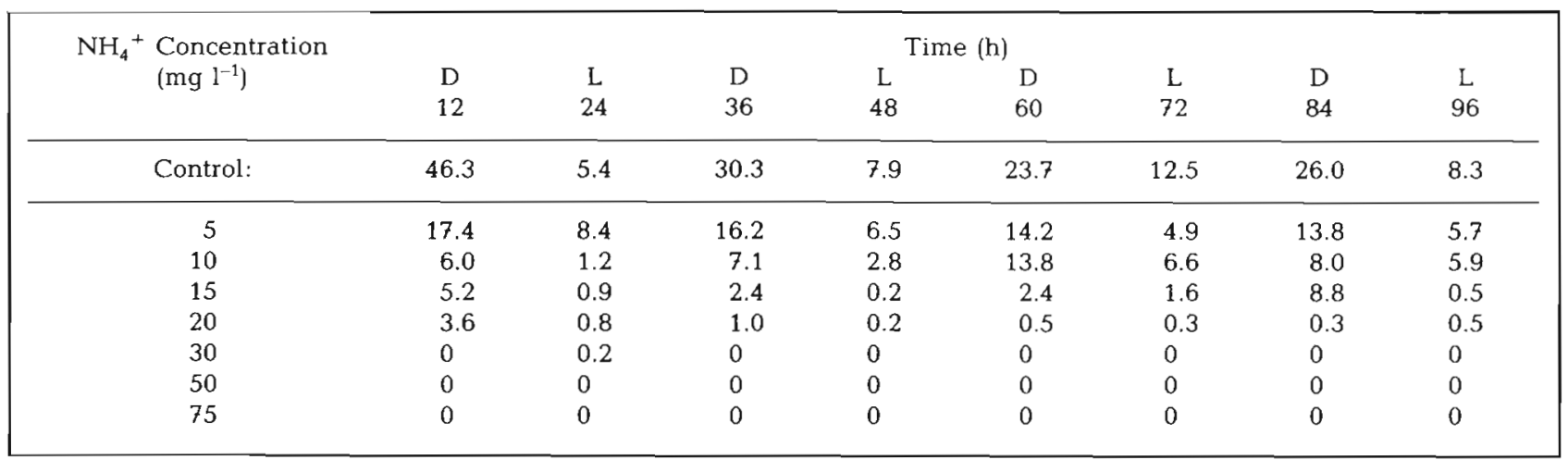


threads are important and useful criteria employed for assessing the activity of the bivalves concerned.

\section{Ammonia}

Results are presented in Table 4 and Fig. 6. Only at 2.75 and $5.50 \mathrm{mg} \mathrm{l}^{-1}$ did Perna viridis produce threads continuously. Byssus-thread production decreased in intensity as a function of increasing ammonia concentration. Individuals exposed to 16.5 and $22.0 \mathrm{mg} \mathrm{l}^{-1}$ did not produce any threads. In the 12 -h interval, the rate of thread production was higher in darkness (1800 to $0600 \mathrm{~h}$ ) than in light condition. The difference was statistically significant ( $p=0.05$ ). The results indicate that continuous exposure to the same concentration will not drastically affect pedal activity. However, the difference in the rate of byssus-thread secretion between the test concentrations employed was highly significant ( $p=0.01$ ). When the total number of byssus threads produced by all mussels exposed to different concentrations was analysed, a sharp decline occurred between individuals kept at 5.50 and $8.25 \mathrm{mg} \mathrm{l}^{-1}$ respectively. The 96 -h $\mathrm{LC} 50$ is $7.60 \mathrm{mg} \mathrm{l}^{-1}$. However, when the percentage of mussels that have secreted byssus threads in different concentrations is taken into consideration, inactivity starts only from $13.75 \mathrm{mg} \mathrm{l}^{-1}$, after 36 -h of exposure (Table 5).

\section{Ammonium}

The intensity of byssus-thread secretion is presented in Table 6 and Fig. 7. In these tests, dark and light regimes influenced considerably the number of byssus threads produced at various ammonium concentrations. Secretion dropped significantly above concentrations at $10.0 \mathrm{mg} \mathrm{l}^{-1}$. The mussels in higher concentrations produced a considerably lower number of threads.
The rate of production was negligible after $12 \mathrm{~h}$ in 15.0 and $20.0 \mathrm{mg} \mathrm{l}^{-1}$. The mussels did not show any byssus production in 50.0 and $75.0 \mathrm{mg} \mathrm{l}^{-1}$. Analysis of variance reveals that the variations between intervals were not statistically significant. However, the difference between concentrations was significant $(\mathrm{P}=0.01)$. The total number of threads produced by any group of test individuals retained in each concentration for $96 \mathrm{~h}$ was also conspicuously different. Similarly, the percentage of test mussels capable of secreting byssus threads dropped clearly above $15.0 \mathrm{mg} \mathrm{l}^{-1}$ (Table 7). The differences between concentrations was significant $(\mathrm{P}=0.01)$.

\section{DISCUSSION}

Both nitrite ion $\left(\mathrm{NO}_{2}{ }^{-}\right)$and ammonia are highly toxic to a wide variety of marine organisms (Becker and Thatcher, 1973). Adult Crassostrea virginica have a median ammonia tolerance limit (96-h TLm) of $0.082 \mathrm{mg} \mathrm{l}^{-1}$ (Epifanio and Srna, 1975). For Mercenaria mercenaria, these limits range from 0.011 to $0.082 \mathrm{ml}^{-1}$ (110 to $880 \mathrm{mg} \mathrm{NH}_{4} \mathrm{Cl} \mathrm{l}^{-1}$ ) for ammonia. C. virginica and $M$. mercenaria are considered very tolerant. The present observations on the LC 50 values show that for $\mathrm{NH}_{3}$, the 48 -h LC 50 is $14.0 \mathrm{mg} \mathrm{l}^{-1}$ and for $\mathrm{NH}_{4}^{+}$ $15.5 \mathrm{mg} \mathrm{l}^{-1}\left[57.2 \mathrm{mg} \mathrm{l}^{-1}\right.$ of $\left.\left(\mathrm{NH}_{4}\right)_{2} \mathrm{SO}_{4}\right]$ in Perna viridis. At the above $\mathrm{NH}_{3}$ concentration, the $\mathrm{pH}$ ranged between 8.70 and 8.85 , for $\mathrm{NH}_{4}^{+}$, the $\mathrm{pH}$ was 8.07 .

The present study demonstrates that the tolerance limits of Perna viridis for $\mathrm{NH}_{3}$ and $\mathrm{NH}_{4}^{+}$are different and that comparatively higher concentrations $(13.0 \mathrm{mg}$ $\mathrm{l}^{-1}$ ) of $\mathrm{NH}_{4}^{+}$could be tolerated up to $96 \mathrm{~h}$. Individuals of $P$. viridis exposed to higher concentrations secreted considerable quantities of mucus and their pseudofaeces showed a gelatinous consistency. The biological consequences of ammonia accumulation have been reviewed in 'Marine Ecology', Volume III by Kinne (1976). In freshwater fishes, high ammonia levels can

Table 7. Perna viridis. Percentage of mussels secreting byssus threads at 12 -h intervals in various $\mathrm{NH}_{4}{ }^{+}$concentrations. $\mathrm{D}=$ dark; $\mathrm{L}=$ light

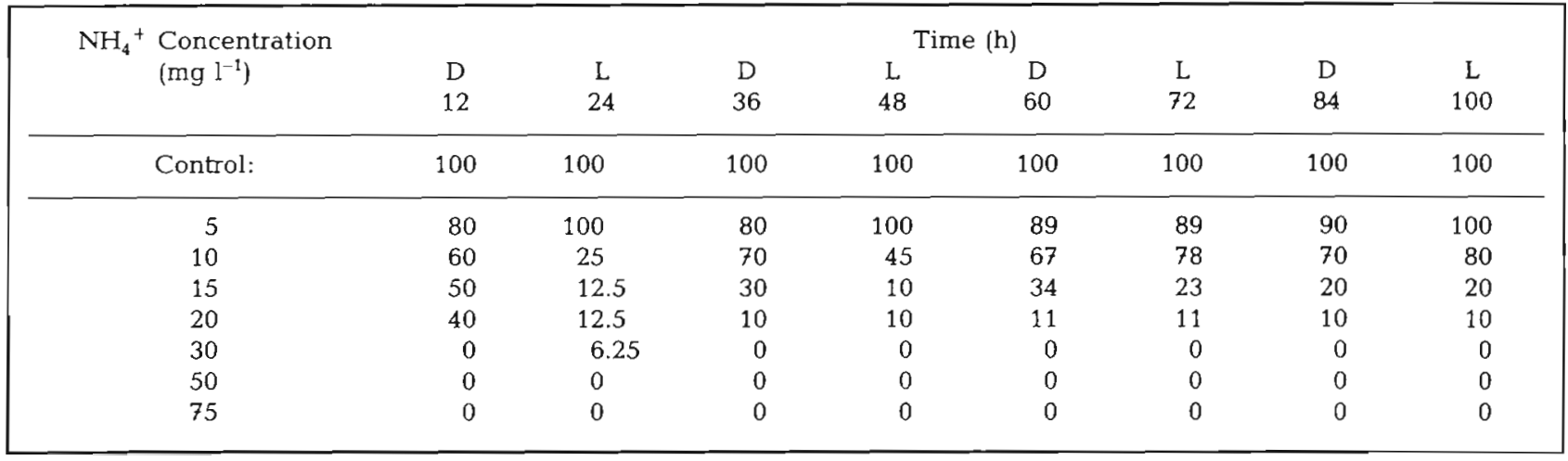


lead to hyperplasia of the gill epithelium. According to Currie et al. (1974), $\mathrm{NH}_{4} \mathrm{NO}_{3}$ concentrations up to $10 \mathrm{ppm}$. have no significant effect on fertilization of Chromytilus meridionalis, although embryonic development was retarded, even at values as low as $0.5 \mathrm{ppm}$. The asymptotic pattern of the ET 50 curve indicates that low $\mathrm{NH}_{4}^{+}$concentrations do not cause lethal effects, indicating that $\mathrm{NH}_{4}^{+}$is less toxic than $\mathrm{NH}_{3}$.

Where Perna viridis has survived ammonia and ammonium exposure, byssus-thread formation tended to be affected negatively and the pedal activity dropped in concentrations just above the threshold levels. The decrease in the activity is more conspicuous in $\mathrm{NH}_{3}$ than $\mathrm{NH}_{4}^{+}$exposed individuals.

The site of $\mathrm{NH}_{3}$ and $\mathrm{NH}_{4}^{+}$entry could be the mantle, gill, gut or the adductor muscle. In general, the rate of $\mathrm{NH}_{3}$ entry through the cell wall is quicker than that of $\mathrm{NH}^{+}{ }_{4}$. Due to increased dissociation of $\mathrm{NH}_{3}$ at $\mathrm{pH}$ values above 8.2 , maintenance of high $\mathrm{pH}$ in the sea water bathing the mantle and gills of $P$. viridis during exposure, will result in an increased $\mathrm{NH}_{3}$ entry into the tissue. $P$. viridis is found to thrive well in sea water where the $\mathrm{pH}$ ranges from 7.8 to 8.6 (Rao and Menon, in press). Hence it may be assumed that, within the above range, $\mathrm{pH}$ is not a limiting factor to normal life processes of $P$. viridis. However, high $\mathrm{pH}$ resulting from the presence of $\mathrm{NH}_{3}$ might lead to cellular damage.

At higher concentrations the byssus threads of Perna viridis showed variations in morphology. The most conspicuous changes were lack of hardening and inability of the adhesive disc to attach firmly. The rate of byssus-thread production is influenced by various environmental factors. These include water movement, salinity, the position occupied by the mussels in the intertidal region, dissolved oxygen concentration, temperature, oil, detergents and mercury salts (Reish and Ayers, 1968; van Winkle, 1970; Roberts, 1975). Improper development of adhesive discs under ammonia stress results in the mussels losing the capacity to attach byssally. During darkness, Perna viridis secretes more byssus threads than when exposed to light.
Acknowledgements. We are thankfull to Prof. H. P. C. Shetty, Director of Instruction, College of Fisheries for the facilities provided and the constant encouragement offered during the investigation. One of us (N. A. Reddy) is grateful to the Indian Council of Agricultural Research, for the award of a Junior fellowship during the tenure of which this work was carried out. We are grateful to the members of the Department of Fishery Hydrography. College of Fisheries for their assistance

\section{LITERATURE CITED}

Becker, C. D. and Thatcher, T. O. (1973). Toxicity of power plant chemicals to aquatic life. U.S. Atomic Energy Commission, Publ., 1249, 1-218.

Brown, A. C. (1974). Observations of the effect of ammonium nitrate solutions on some common marine animals from Table Bay. Trans. R. Soc. S. Afr., 41, 217-223.

Brown, A.C. and Currie, A. B. (1973). Tolerance of Bullia digitalis (Prosobranchiata) to solutions of ammonium nitrate in natural sea water. S. Afr. J. Sci., 69, 219-220.

Currie, A. B., Brown, A. C. and Bennet, G. R. (1974). The effect of ammonium nitrate solutions on some aspects of the biology of the black mussel, Cheromytilus meridionalis. Trans. R. Soc. S. Afr., 41, 209-215.

Epifanio, C. E. and Sma, R. F. (1975). Toxicity of ammonia, nitrite ion, nitrate ion, and orthophosphate to Mercenaria mercenaria and Crassostrea virginica. Mar. Biol., 33, 241-246.

Kinne, O. (1976). Cultivation of marine organisms: water quality management and technology. In O. Kinne (Ed.), Marine Ecology, Vol. III, Cultivation, Part 1. Wiley, London. pp. 19-300

Kuriakose, P. S. and Nair, N. B. (1976). The genus Perna along the coasts of India with description of a new species Perna indica. Aquat. Biol., 1, 25-36.

Rao, D. S. K. and Menon, N. R. (in press). Settlement characteristics on different substrata by three commercially important bivalves in Mangalore waters, Arabian Sea. Int. Revue ges. Hydrobiol.

Reish, D. J. and Ayers, J. L. (1968). Studies on the Mytilus edulis community in Alamitos Bay, Califomia. II. The effects of reduced oxygen concentration on survival and byssus thread formation. Veliger, 10, 384-388.

Roberts, D. (1975). The effect of pesticides on byssus formation in the common mussel, Mytilus edulis. Environ. Pullut., 8, 241-254.

Van Winkle, W., Jr. (1970). Effect of environmental factors on byssal thread formation. Mar. Biol., 7, 143-148. 